\title{
PENGARUH USIA LANJUT TERHADAP HASRAT SEKSUAL PRIA
}

\author{
Claudia A. Putong, Lydia Tendean, Benny Wantouw \\ Bagian Biologi dan Andrologi, Fakultas Kedokteran, UNSRAT, Manado
}

\begin{abstract}
Nowadays there is an increasing prevalence of elder people all around the world, including Indonesia. With increasing age, several health problems occurred, such as the influence of older age to sexual desire which is commonly occurred in elder men. This is a descriptive-observational study, which is aimed to evaluate the influence of aging to sexual desire in male. 57 men aged 60-74 years on the area of Prof Dr. R. D. Kandou Hospital from November 2013 to January 2014 were involved in this research. Instruments that were used in this research are ADAM (Androgen Deficiency in Aging Male) questionnaire and AMS (Aging Male Symptoms) questionnaire to assess the sexual function in elder men. This study showed that among 57 respondents aged 60-74 years old, through ADAM and AMS questionnaire, 28 (49\%) subjects had mild orgasm dysfunction, 27 (47,4\%) subjects had moderate decrease in sexual coitus, 24 (42\%) subjects had mild decrease in sexual desire, and 29 (51\%) subjects had mild erection dysfunction. Older age influence the sexual function in men. Further studies using larger samples and complete research procedures, including laboratory examination, are needed to assess the influence of older age to male sexual desire.
\end{abstract}

Keywords : older age, male, sexual desire

Abstrak : Dewasa ini jumlah penduduk usia lanjut (60 tahun ke atas) di seluruh dunia, termasuk di Indonesia, mengalami peningkatan. Seiring dengan peningkatan usia, terjadi berbagai masalah kesehatan, termasuk di antaranya adalah pengaruh usia lanjut terhadap hasrat seksual yang banyak terjadi pada pria usia lanjut. Penelitian ini bertujuan untuk mengetahui pengaruh usia lanjut terhadap hasrat seksual pria. Desain penelitian adalah observasional deskriptif. Sebanyak 57 orang pria usia lanjut berusia 60-74 tahun yang berada di area RSUP Prof. Dr. R. D. Kandou Manado pada periode November 2013 hingga Januari 2014 menjadi subjek di dalam penelitian ini. Instrumen yang digunakan dalam penelitian ini adalah kuesioner ADAM (Androgen Deficiency in Aging Male) dan AMS (Aging Male Symptoms) untuk menilai fungsi seksual pada pria usia lanjut. Hasil penelitian menunjukkan bahwa sebanyak 57 responden dengan rentang usia 60-74 tahun melalui kuesioner ADAM dan AMS didapatkan 28 orang (49\%) gangguan orgasme ringan, 27 orang $(47,4 \%)$ penurunan frekuensi senggama sedang, 24 orang (42\%) penurunan hasrat seksual ringan dan 29 orang (51\%) gangguan ereksi ringan. Usia lanjut berpengaruh terhadap hasrat seksual pada pria. Studi lanjutan dengan jumlah sampel lebih banyak dan prosedur penelitian lebih lengkap, mencakup pemeriksaan laboratorium, diperlukan untuk meneliti lebih jauh mengenai pengaruh usia lanjut terhadap hasrat seksual pria.

Kata kunci : usia lanjut, pria, hasrat seksual 


\section{PENDAHULUAN}

Usia lanjut adalah orang yang telah mencapai usia 60 tahun keatas. Sebagian orang yang berada di lingkungan keluarga masih dapat memberikan kontribusi dalam menunjang keberhasilan kehidupan ekonomi keluarga. ${ }^{1}$

Organisasi kesehatan

dunia (WHO) menetapkan 65 tahun sebagai seseorang yang disebut usia lanjut. Organisasi Kesehatan Dunia (WHO) menggolongkan lanjut usia menjadi 4 yaitu : usia pertengahan (middle age) 45 -59 tahun, usia lanjut (elderly) 60 -74 tahun, lanjut usia tua (old) 75 - 90 tahun dan usia sangat tua (very old) diatas 90 tahun. ${ }^{2}$ Departemen Kesehatan RI menetapkan seseorang dengan usia lebih dari 60-69 tahun, sebagai usia lanjut resiko tinggi. ${ }^{3}$ Struktur penduduk dunia termasuk Indonesia saat ini menuju proses penuaan yang ditandai dengan meningkatnya jumlah dan proporsi penduduk usia lanjut. Proporsi penduduk usia lanjut di Indonesia mengalami peningkatan cukup signifikan selama 30 tahun terakhir dengan populasi 5,3 juta jiwa dari 4,48 persen total keseluruhan penduduk Indonesia pada tahun 1971 menjadi 19,3 juta dari 8,37 persen total keseluruhan penduduk Indonesia pada tahun 2009. ${ }^{4}$ Proses menua pada akhirnya adalah proses yang terus menerus secara alamiah yang dimulai sejak lahir serta umumnya dialami oleh semua makhluk hidup. Gejala menua adalah proses hilangnya secara perlahan kemampuan jaringan untuk memperbaiki diri atau mengganti dan mempertahankan fungsi normalnya sehingga tidak dapat bertahan terhadap infeksi dan memperbaiki kerusakan yang diderita, tidak terkecuali dalam hal hasrat seksual (libido). ${ }^{6}$

Gangguan hasrat seksual didefinisikan sebagai tidak adanya atau berkurangnya rasa ketertarikan atau hasrat seksual. Dalam hal ini tidak ada pikiran 
atau fantasi seksual dan respon terhadap hasrat seksual tersebut. Motivasi sebagai faktor pendorong untuk berusaha membangkitkan gairah seksual jarang atau bahkan tidak ada. Hilangnya ketertarikan atau kurangnya hasrat seksual berhubungan dengan respon seksual manusia. ${ }^{7-11}$

Gangguan hasrat seksual pada pria dapat dikarenakan oleh endokrinopati yang diatur oleh sistem saraf pusat yang selanjutnya akan mempengaruhi kelenjar hipofise anterior yang bertanggung jawab dalam menghasilkan LH dan FSH dalam memproduksi testosteron. Hormon ini sering dianggap sebagai hormon seks sehingga sangat berpengaruh pada ritme biologis, dan perilaku seksual. $^{12}$

Kekurangan hormon testosteron di usia lanjut dapat menyebabkan pergolakan emosional yang tidak jarang membuat pria menjadi depresi dan menimbulkan ketakutan serta restrukturisasi kognitif pasangan dalam hubungan seksual. 13,14

\section{KERANGKA TEORITIS}

Penelitian ini berpijak dari suatu pemikiran dasar bahwa usia lanjut yang merupakan faktor alamiah berpengaruh pada hasrat seksual pada pria yang dikarenakan penurunan hormon testosteron, prolaktin, Luteinizing Hormone, Follicle Stimulating Hormone, Growth Hormone.

\section{METODOLOGI PENELITIAN}

Penelitian ini merupakan suatu penelitian observasional deskriptif. ${ }^{15}$ Penelitian dilakukan di RSUP Prof. Dr. R. D. Kandou Manado pada periode November 2013 hingga Januari 2014. Populasi penelitian adalah seluruh pria usia lanjut di Manado. sampel penelitian adalah seluruh pria usia lanjut yang memenuhi criteria inklusi dan eksklusi. Tingkat ketepatan absolut yang dikehendaki adalah 5\%. Maka jumlah sampel yang didapatkan 
adalah 133. Kriteria inklusinya adalah pria usia lanjut usia 60-74 tahun. Kriteria eksklusi adalah riwayat penyakit DM, infertil, trauma akut testis, penyakit ginjal kronik, undensensus testis, dan sindrom Klinefelter. Pada saat bertemu dengan pria usia lanjut, perlu dijelaskan tujuan menjawab kuesioner. Dalam penelitian ini kuesioner yang digunakan adalah kuesioner ADAM (Androgen Deficiency in Aging Male) dan AMS (Aging Male Symptoms) untuk menilai fungsi seksual pada pria usia lanjut. Perlu ditanyakan juga adanya penyakit penyerta. Jika sesuai dengan kriteria inklusi maka responden dapat menandatangani lembar persetujuan. Lalu selanjutnya responden dapat mulai menjawab kuesioner yang diberikan.

\section{HASIL DAN PEMBAHASAN}

Selama jangka waktu penelitian mulai bulan november 2013 sampai januari 2014, telah dilakukan penelitian terhadap 57 pria usia lanjut. Selama penelitian ini terdapat 15 responden pada rentang berusia 60-65 tahun, 24 responden pada rentang usia 66-70 tahun, dan 18 responden pada rentang usia 71-74 tahun. Yang tidak mengalami penurunan hasrat seksual adalah sebanyak 6 orang (10,6\%), penurunan hasrat seksual ringan 24 orang (42\%), penurunan hasrat seksual sedang 21 orang (37\%), penurunan hasrat seksual berat 5 orang $(8,8 \%)$ dan penurunan hasrat seksual berat sekali sebanyak 1 orang (1,8\%).

\section{Pembahasan}

Usia berhubungan dengan penurunan secara progresif fungsi fisik dan koqnitif manusia. Pengaruh usia sangat tergantung pada perubahan hormon endrokrin yang diatur oleh sistem saraf pusat yang mempengaruhi perilaku neural dinamik, neurodegenerasi, koqnitif ritme biologis, perilaku seksual dan sistem metabolisme. Pengaruh umur juga mempengaruhi kadar glucocoticoids, cytokines, dan penurunan produksi 
steroid seks GH (growth hormone) dan IGF (insulin growth factor). ${ }^{16}$

Pengetahuan akan ilmu molekuler memberikan pemahaman yang lebih akan pengaruh penuaan dalam hubungannya dengan sistem endokrin dan sistem saraf pusat. Penurunan kadar GH dan steroid seks di dalam darah, biasanya dinyatakan sebagai somatopause, menopause, dan andropause. Satu hal yang penting dalam hubungannya dengan umur adalah pola pulsasi dan amplitudo pengeluaran hormon. Frekuensi pengeluaran hormon memang penting, tetapi yang lebih penting adalah jumlah hormon yang dikeluarkan. ${ }^{16}$

Pertambahan usia juga berpengaruh terhadap perubahan metabolisme yang mengakibatkan peningkatan kandungan lemak dan berkurangnya massa otot. Hal ini akan mengakibatkan seorang pria menderita penyakit metabolisme, seperti diabetes, hiperlipidemia, arteriosklerosis, dan hipertensi. Perubahan metabolisme ini berhubungan dengan penurunan GH (Growth Hormone), IGF-I (Insulin-like growth factor 1), dan kadar seks steroid akibat peningkatan produksi glukokortikoid dan juga resistensi insulin serta leptin. ${ }^{16}$

Pria dan wanita memproduksi hormon yang persis sama, walaupun fakta ini sering dilewatkan. Kebanyakan kadar hormon pada pria menjadi lebih rendah saat pria semakin tua. Usia 52 tahun merupakan usia dimana pria mulai merasakan transisi tengah baya. Jelasnya, awal 50-an merupakan periode waktu yang paling mungkin untuk pertama kalinya disadari oleh pria akan adanya tandatanda penurunan hasrat seksual. Pada pria usia lanjut, fungsi baik testis maupun aksis hipotalamus-hipofise berkurang, yang mempengaruhi produksi hormon testosteron yang pada akhirnya juga akan berkurang. Karakteristiknya meliputi turunnya energi, hasrat seksual, stamina, dan rasa bahagia. ${ }^{13}$

\section{KESIMPULAN DAN SARAN}

Dari hasil penelitian ini dapat disimpulkan bahwa usia lanjut berpengaruh terhadap hasrat seksual pada pria dan penurunan hasrat seksual pada pria usia lanjut diakibatkan oleh 
faktor usia, penurunan hormon testosteron, prolaktin, Luteinizing Hormone, Follicle Stimulating Hormone, Growth Hormone, penyakit penyerta dan tingkat stress yang berlebihan.

Berdasarkan penelitian ini maka dapat disarankan bahwa Perlu dilakukan penelitian lanjutan dengan pemeriksaan skrining awal yang lengkap sehingga faktor lain yang menyebabkan penurunan hasrat seksual pada pria dapat dikendalikan dan Untuk pemeriksaan skrining hasrat seksual pria sebaiknya selain dengan kuesioner dapat dilengkapi dengan pemeriksaan laboratorium kadar testosteron darah.

\section{DAFTAR PUSTAKA}

Kementrian sosial RI. Perenungan dalam bulan lanjut usia Nasional. Jakarta : 2013

World Health Organization. Penggolongan Lanjut Usia. (kumpulan-materi.com/2012.htm di akses pada 10 september 2013)

Depkes RI. Penyakit tidak menular lansia. 2005. (http://www.scribd.com/doc/makala h epidemiologi penyakit tidak menular lansia di akses pada 4 september 2013)

Badan Pusat Statistik. Profil penduduk lanjut Usia. Jakarta : KOMNAS Lansia. 2009

Wahyudi, Nugroho. Lansia. (http://www.annehira.com/lansia.ht m diakses pada 4 september 2013)

Lunde I, Larson GK, Fog E, Garde K.199Sexual Desires Orgasm and Sexual Fantasies. A Study of 265 Danish Woman Born in 1910, 1936 and 1958. Sex Educ 1991:431-7.

Hill C A, Preston L K. Individual Differences in The Experience of Sexual Motivation. Theory and Measurement of Dispositional Sexual Motives. 33(1);27-45.

Galyer K T, Conaglen H M, Hake A, Conaglen J V. The Effect of Gynecological Surgery on Sexual Desires. Sex Marntal 1999;25:81-8.

Regan P, Berscheid E B. About the Stat Goals and Objects of Sexual Desires. Sex Mantal 1996;22:11020. 
Klusmann D. 2002. Sexual Motivation and The Duration of Woman. Population Based Epidemiological Study Arch Womens Ment Health. (2);59-63

Sheryl A K. The Impact of Aging on Sexual Function in Woman an Their Partners. Archives of Sexual Behavior 2002;31(5):431-7.

Platt, M. 2007. The miracle of BioIdentical Hormones. Prabantini dwi. 2010. Yogyakarta. ANDI

Santrock J W .2002. Definisi Lanjut Usia. (kumpulan materi.blogspot.com/2012/01 diakses pada 10 september 2013)

Dean J. 1998. Examination of Patiens with Sexual Problems. Clinical Review. Vol 317

Sastroasmoro S, Ismael S. 2011. Metodologi Penelitian Klinis Edisi ke 4. Sagung Seto. Jakarta 